\title{
Finansal Okuryazarlığın İncelenmesi: Sağlık Yönetimi Bölümü Öğrencilerinde Bir Uygulama
}

\author{
Özlem 0̈zer@
}

Burdur Mehmet Akif Ersoy Üniversitesi, İktisadi ve İdari Bilimler Fakültesi, Sağlık Yönetimi Bölümü, Burdur, Türkiye

Özlem Özer, Dr. Öğr. Üyesi

Iletişim:

Dr. Öğr. Üyesi Özlem Özer Burdur Mehmet Akif Ersoy Üniversitesi, Iktisadi ve İdari Bilimler Fakültesi, Sağlı Yönetimi Bölümü, Burdur, Türkiye Tel: +902482132500

E-Posta: 00zer@mehmetakif.edu.tr

Gönderilme Tarihi : 06 Ekim 2017

Revizyon Tarihi : : 06 Ekim 2017

Kabul Tarihi $\quad$ : 02 Kasım 2017
ÖZET

Amaç: Bu çalışmanın amacı, sağlık yönetimi bölümü öğrencilerinin finansal okuryazarlık düzeylerini belirlemek ve demografik özelliklerin finansal okuryazarlık üzerinde etkili olup olmadığını ortaya koymaktır.

Gereç ve Yöntem: Çalışmanın evrenini, Türkiye'deki bir devlet üniversitesinin İktisadi ve İdari Bilimler Fakültesi'nde eğitim görmekte olan Sağlık Yönetimi bölümü öğrencileri oluşturmaktadır. Araştırmada örneklem seçilmemiş, bütün evrene (345) ulaşılmaya çalışılmış ve toplam 276 kişiden veri elde edilmiştir. Veriler anket tekniğiyle toplanmıştır. Verilerin analizinde tanımlayıcı istatistikler, iki ortalama arasındaki farkın önemlilik testi ve tek yönlü varyans analizi (ANOVA) kullanılmıştır.

Bulgular: Çalışma bulguları, öğrencilerin ilgi, tutum ve harcama boyutları için cinsiyete göre istatistiksel olarak anlamlı olduğunu göstermektedir. Ayrıca çalışmada ilgi, algı ve harcama boyutlarında ikamet edilen yere göre istatistiksel olarak anlamlı bir fark tespit edilmiştir.

Sonuç: Çalışmada öğrencilerin finansal okuryazarlık algılarının alt boyutlar bazında orta seviyede olduğu belirlenmiştir.

Anahtar sözcükler: finansal okuryazarlık, sağlık yönetimi öğrencileri

INVESTIGATION THE LEVEL OF FINANCIAL LITERACY: AN APPLICATION ON STUDENTS OF HEALTH MANAGEMENT DEPARTMENT

\section{ABSTRACT}

Aim: The aim of this study is to determine the financial literacy levels of health management department students and to reveal the demographic features of the students and to determine whether it has an effect on the perception of financial literacy or not.

Methods: The population of the study is composed of students from the Department of Health Management who are training in the Faculty of Economics and Administrative Sciences at a state university in Turkey. The sample was not selected in the study, tried to reach the whole universe (345) and the data were obtained from a total of 276 students. Data were collected by questionnaires. Descriptive statistics, significance test of two means, oneway analysis of variance (ANOVA) were used.

Results: The study findings showed that interest, attitude and expenditure sub-scales of financial literacy perceptions of the students were found to be statistically significant in terms of gender. In addition, interest, perception and expenditure sub-scales of financial literacy were found to be statistically and significantly different in terms of place of residence.

Conclusion: In the study, the perceptions of students, associated with financial literacy were determined as a medium-level on the basis of sub-dimensions.

Keywords: Financial literacy, health management students 
$\mathbf{F}$ inansal okuryazarlık, gittikçe karmaşık hale gelen finans dünyasında bireylerin sağlıklı bir şekilde finansal kararlar alabilmeleri için gerekli olan ve son yıllarda da önemi hızla artan bir kavramdır (1). Finansal okuryazarlık; özellikle hükümetler, bankacılar, işverenler, finansal piyasalar ve diğer kuruluşların da dâhil olduğu çeşitli grupların ilgisini çeken bir konudur. Yeni finansal ürünlerin gelişimi, finansal piyasaların karmaşıklığı ve politik, demografik ve ekonomik faktörlerin değişimi gibi unsurlar nedeniyle de finansal okuryazarlığın geliştirilmesinin önemi son yıllarda daha da artmıştır (2).

Finansal okuryazarlık, insanların gündelik hayatlarında üstesinden gelmek zorunda olduğu sorunlarla ilgili finansal ürünler hakkındaki bilgisi ve anlayışı olarak tanımlanmaktadır (3). Remund (2010)'a göre finansal okuryazarlık; değişen ekonomik koşulları ve yaşam olaylarını göz önünde bulundururken, uygun kısa vadeli karar alma ve uzun vadeli finansal planlama için temel finansal kavramları anlama ve kişisel finansmanı yönetme kabiliyetine sahip olmayı ölçen bir ölçüttür. Kısacası finansal okuryazarlık, bir kişinin parayı idare etme yetkinliği ile ilgilidir (4). Ekonomik İşbirliği ve Kalkınma Örgütü ise finansal okuryazarlığı, finansal kararlar almak ve sonuç olarak bireysel finansal refahı sağlamak için gerekli farkındalık, bilgi, beceri, tutum ve davranışın bir bileşimi olarak kavramlaştırmaktadır (5). Huston (2010) ise finansal okuryazarlığın iki boyuttan oluştuğunu ifade etmektedir. Bunlardan birincisi, kişisel finansal bilgiyi veya finansal eğitimi yansıtan anlayıştır ve diğeri de kişisel finans yönetiminde bu bilgilere başvurarak bilgilerin kullanılabilmesidir (6).

Finansal okuryazarlık, tüketicilerin bir şekilde hayatları ile ilgili olan finansman konularında bilgi sahibi olmalarına ve bu bilgiyi, ürünleri değerlendirmek ve bilinçli kararlar vermek için kullanmalarına izin verir. Ayrıca tasarruf etmek, varlıkları çeşitlendirmek ve sigorta satın almak gibi riskleri hafifleten stratejiler aracılığıyla tüketicileri zorlu finansal durumlara karşı hazırlar (7).

Finansal okuryazar olmak, tüketicilerin finansal refahlarını sağlayabilmeleri amacıyla hem finansal sistemin kendileri için ortaya çıkardığı avantajlardan yararlanabilmeleri açısından hem de finansal sistemde oluşabilecek piyasa aksaklıkları ile haksız uygulamalardan korunabilmeleri açısından oldukça önemlidir (8). Finansal konularda bilgi ve beceri sahibi olan bireyler kısa ve uzun dönemli ihtiyaçları ile ilgili daha doğru kararlar verebilmekte, finansal ürünler arasında daha bilinçli seçimler yapabilmektedir. Ayrıca bu kişiler, ihtiyaçları olmayan hizmet ve ürünleri satın almaktan kaçınmakta ve kendilerini finansal açıdan sıkıntıya sokabilecek riskleri üstlenmemektedir (9). Finansal okuryazarlık konusunda bilgi eksikliği durumu ise; efektif olmayan finansal davranışa, tasarruf eksikliğine, finansal kayıtları dikkatle tutmamaya ve daha yüksek kredi borçlarına neden olabilmektedir (10). Gökmen (2012) finansal okuryazar bir bireyin 1) parasını iyi yönetebilme, 2) finansal sistemin işleyiş̧ini anlayabilme, 3) finansal planlar yapabilme ve 4) iyi iletişim kurabilme gibi bir takım bilgi, beceri, tutum ve davranışlara sahip olması gerektiğini belirtmektedir (11).

İnsanların, ne satın alacakları, satın aldıkları şey için nasıl ödeme yapacakları ve finansal yükümlülüklerini zamana nasıl yaymaları gerektiği konusunda kararlar alması gerektiği durumlarda finansal okuryazarlık sosyal refah için de çok önemli bir konudur (3). Huston (2010) finansal okuryazarlığı, tüketimden ömür boyu beklenen faydayı (örneğin finansal refahı artıran davranışlar) artırmak için finansal faaliyetlerde kullanılabilen beşeri sermayenin bir bileşeni olduğunu ifade etmektedir. Ayrıca diğer etkilerin (davranışsal / bilişsel önyargılar, kendi kendini kontrol sorunları, aile, akran, ekonomik, topluluk gibi) finansal davranışları ve finansal refahı etkilediğini ve finansal açıdan okuryazar olan (diğer bir deyişle bilgiyi kullanma ve bilgiyi kullanma becerisine sahip olan) bir kişinin, bu diğer etkiler nedeniyle finansal refahında beklenen davranışları veya artışları sergileyemeyeceğini belirtmektedir (6).

Literatürde bireylerin finansal okuryazarlığının ölçülmesinde standartlaştırılmış bir yaklaşım geliştirilememiştir. Huston (2010)'a göre standartlaştırılmış bir yaklaşım geliştirilememesinin önünde üç temel engel bulunmaktadır. Bu engeller ise (6);

- Kavramlaştırma eksikliği,

- Finansal okuryazarlık yapısının tanımlanmasındaki eksiklikler ve

- Finansal okuryazarlık aracının içeriği ve yorumlanmasındaki eksikliklerdir.

Toplumda her bir bireyi yakından etkileyen finansal okuryazarlık kavramının dikkatli bir şekilde incelenmesi gerekmektedir. Örneğin finansal yenilikler, tüketiciler için yeni fırsatlar geliştirmekle beraber, finansal seçenekleri değerlendirmede ve daha karmaşık finansal ürünleri anlamada güçlük çeken finansal tüketiciye daha yüksek riskler yüklemektedir (12). 
Finansal okuryazarlık, üniversite öğrencileri için dikkate alınması gereken bir kavramdır. Üniversite öğrencilerinin geleceğin yetişkinleri olarak daha kaliteli bir yaşam sürdürmek ve daha iyi yaşam standartlarına ulaşabilmek için doğru ve etkin finansal kararlar vermeleri gerekmektedir. Öğrencilerin finansal piyasaları ve finansal piyasaların işleyişini anlaması, finansal ürünleri tanıması, doğru finansal ürün tercihinde bulunabilmesi, finansal ürün ve hizmetleri etkin bir şekilde kullanabilmesi için finansal okuryazarlık düzeyinin yüksek olması gerekmektedir (13). Bu yüzden üniversite öğrencilerinin finansal okuryazarlığa yönelik tutum ve davranışlarını değerlendirmek önemli bir konudur. Literatürde ise sağlık yönetimi bölümü öğrencilerinde finansal okuryazarlık düzeylerini inceleyen çalışma sayısının yetersiz olması bu çalışmanın temel çıkış noktasını oluşturmaktadır.

\section{Çalışmanın amacı}

Bu çalışmanın amacı, sağlık yönetimi bölümü öğrencilerinin finansal okuryazarlık düzeylerini belirlemek ve demografik özelliklerin finansal okuryazarlık üzerinde etkili olup olmadığını ortaya koymaktır.

\section{Gereç ve yöntem}

Evren ve örneklem

Çalışmanın evrenini, Türkiye'deki bir devlet üniversitesinin İktisadi ve İdari Bilimler Fakültesi'nde eğitim görmekte olan Sağlık Yönetimi bölümü öğrencileri oluşturmaktadır. Araştırmada örneklem seçilmemiş, bütün evrene (345) ulaşılmaya çalışıımış ve araştırmada kullanılan veri toplama aracı araştırmaya katılmayı kabul eden tüm öğrencilere dağıtılmıştır. Veri toplama süreci 18 Eylül - 22 Eylül 2017 tarihleri arasında gerçekleştirilmiş ve toplam 276 adet kullanılabilir anket elde edilmiştir. Böylece çalışmaya katıım oranı $\% 80$ olarak belirlenmiştir.

\section{Veri toplama aracı}

Çalışmada finansal okuryazarlık düzeyini ölçmek için Sarıgül (2015) tarafından geliştirilen toplam 14 maddeden ve harcama (4 madde), tutum (4 madde), algı (3 madde), ilgi (3 madde) olmak üzere 4 alt boyuttan oluşan "Finansal Okuryazarlık Tutum ve Davranış Ölçeği" kullanılmıştır (14). Ölçekte her bir soru maddesinin cevap skalası "tamamen katılıyorum" ifadesinden "hiç katılmıyorum" ifadesine kadar uzanan 5'li Likert ölçeği şeklindedir. Bu çalışmada ölçeğin güvenirlik değeri $a=0,602$ olarak belirlenmiştir. Çalışmada kullanılan ölçeğin geçerliliğini test etmek için faktör analizi yapılmıştır. Finansal okuryazarlık ölçeğine uygulanan faktör analizi sonuçlarına göre ise, ölçeğin bu çalışmada Sarıgül (2015)'ün çalışması ile benzer olarak dört boyutlu bir yapı sergilediği görülmüştür. Dört boyutlu yapının toplam varyansın \%52,236'sını açıkladığı belirlenmiştir.

\section{Verilerin analizi}

Tüm istatistiksel analizler Statistical Package for The Social Science v20.0 (SPSS; http://spss.com) kullanılarak gerçekleştirilmiştir. Verilerin analizinde tanımlayıc analizler, güvenirlik analizi, korelasyon analizinden yararlanılmıştır. Çalışmada yaş, cinsiyet, iş deneyimi arasındaki farklıı̆̆ı test etmek için iki bağımsız grupta t testi kullanılırken; sınıf düzeyi, ikamet edilen yer ve ortalama aylık aile geliri arasındaki farklılığı test etmek için tek yönlü varyans analizi kullanılmıştır. Varyans analizinde farklılığın hangi grup ya da gruplardan kaynaklandığının belirlenmesi için ise Tukey testinden yararlanılmıştır.

\section{Çalışmanın İzni}

Çalışmanın yapılabilmesi için ilgili kurumdan gerekli izinler alınmıştır. Öğrencilere anket uygulaması aşamasında ise gönüllülük ilkesi doğrultusunda hareket edilmiştir.

\section{Bulgular}

Tablo 1'de görüldüğü gibi, araştırmaya katılanların \%50,7'si 20 yaş ve üzerindedir ve \%70,7'si kızdır. Katılımcıların \%36,2'si birinci sınıf, \%33,7'si ikinci sınıf, \%17,0'ı üçüncü sınıf ve \%13,0'ı dördüncü sınıf öğrencisidir. Öğrencilerin \%49,3'ü yurtta, \%24,3'ü apart/pansiyonda kalmaktadır. Öğrencilerin \%29,7'si ortalama aylık gelirinin 1001-1500 TL arasında olduğunu belirtirken; \%57,6'sı aylık olarak gelirini idare eder şeklinde değerlendirmiştir. Ayrıca öğrencilerin $\% 41,7^{\prime}$ si iş deneyimine sahip olduğunu $\% 58,3^{\prime}$ ü ise iş deneyimine sahip olmadığını belirtmiş̧tir.

Tablo 2'de yer alan araştırma değişkenlerine ilişkin temel istatistiklere bakıldığında, finansal okuryazarlık alt boyutları arasında en yüksek ortalamayı ilgi $(3,14 \pm 0,76)$ boyutunun ve en düşük ortalamayı ise tutum boyutunun $(1,98 \pm 0,66)$ aldığı dikkat çekmektedir. Genel olarak araştırmaya katılan öğrencilerin finansal okuryazarlık algılarının orta seviyede olduğu söylenebilir. Yapılan korelasyon analizi sonucuna göre ise finansal okuryazarlık alt boyutları arasında anlamlı pozitif ilişkiler bulunmaktadır.

Tablo 3'te araştırmaya katılan öğrencilerin finansal okuryazarlık ölçeğinin alt boyutlarına ilişkin puanları yaş, cinsiyet, sınıf düzeyi, ikamet edilen yer, ortalama aylık aile geliri ve iş deneyimi gibi çeşitli değişkenlere göre karşılaştırılmış ve yürütülen test sonuçları verilmiştir. 
Tablo 1. Katılımcıların demografik özellikleri

\begin{tabular}{|c|c|c|}
\hline Özelikler & $N$ & $\%$ \\
\hline \multicolumn{3}{|l|}{ Yaş } \\
\hline $19 \leq$ & 136 & 49,3 \\
\hline $20 \geq$ & 140 & 50,7 \\
\hline \multicolumn{3}{|l|}{ Cinsiyet } \\
\hline $\mathrm{KIZ}$ & 195 & 70,7 \\
\hline Erkek & 81 & 29,3 \\
\hline \multicolumn{3}{|l|}{ Sınıf Düzeyi } \\
\hline Birinci Sınif & 100 & 36,2 \\
\hline İkinci Sınıf & 93 & 33,7 \\
\hline Üçüncü Sınıf & 47 & 17,0 \\
\hline Dördüncü Sınıf & 36 & 13,0 \\
\hline \multicolumn{3}{|l|}{ İkamet Ettiğiniz Yer } \\
\hline Aile/Akraba yanında & 29 & 10,5 \\
\hline Yurtta & 136 & 49,3 \\
\hline Arkadaşlarımla birlikte/Tek başına evde & 44 & 15,9 \\
\hline Apart/Pansiyon & 67 & 24,3 \\
\hline \multicolumn{3}{|l|}{ Ortalama Aylık Aile Geliri } \\
\hline 1000 TL'den az & 66 & 23,9 \\
\hline $1001-1500 \mathrm{TL}$ & 82 & 29,7 \\
\hline $1501-2000 \mathrm{TL}$ & 63 & 22,8 \\
\hline 2001 TL ve üstü & 65 & 23,6 \\
\hline \multicolumn{3}{|l|}{$\begin{array}{l}\text { Aylık olarak gelirinizin yeterliliğini nasıl } \\
\text { değerlendiriyorsunuz? }\end{array}$} \\
\hline Yeterli & 52 & 18,8 \\
\hline İdare Eder & 159 & 57,6 \\
\hline Yetersiz & 65 & 23,6 \\
\hline \multicolumn{3}{|l|}{ İş Deneyimi } \\
\hline Var & 115 & 41,7 \\
\hline Yok & 161 & 58,3 \\
\hline Toplam & 276 & 100 \\
\hline
\end{tabular}

Tablo 2. Araştırma değişkenlerine ait ortalamalar, standart sapmalar ve korelasyon değerleri

\begin{tabular}{lcccccc} 
Değişkenler & Ortalama & $\begin{array}{c}\text { Standart } \\
\text { Sapma }\end{array}$ & $\mathbf{1}$ & $\mathbf{2}$ & $\mathbf{3}$ & $\mathbf{4}$ \\
\hline İlgi (1) & 3,14 & 0,76 & 1 & & & \\
Tutum (2) & 1,98 & 0,66 & $0,186 * *$ & 1 & & \\
Algı (3) & 2,07 & 0,88 & $0,119 *$ & $0,291 * *$ & 1 & \\
Harcama (4) & 2,71 & 0,66 & $0,182 * *$ & $0,394 * *$ & $0,256 * *$ & 1 \\
\hline${ }^{*} p<0.05,{ }^{* *} p<0.01$ & & & & &
\end{tabular}

Katılımcıların ilgi alt boyutuna vermiş oldukları puanları çeşitli değişkenlere göre karşılaştıran test sonuçlarına bakıldığında, katılımcıların bu boyuta ilişkin puanlarının cinsiyet $(t=5,666 ; p<0,05)$, ikamet edilen yer $(F=4,058$; $p<0,05)$ ve iş deneyiminin olup olmamasına ( $t=-2,941$; $p<0,05)$ göre istatistiksel olarak anlamlı farklılıklar gösterdiği görülmektedir. Buna göre kızların, apart/pansiyonda kalanların ve iş deneyimi olmayanların ilgi boyutuna ilişkin algıları istatistiksel olarak anlamlı şekilde daha yüksektir.

Tablo 3'de katılımcıların tutum alt boyutuna vermiş oldukları puanları çeşitli değişkenlere göre karşılaştıran test sonuçlarına bakıldığında, katılımcıların bu boyuta ilişkin puanlarının sadece cinsiyetlerine $(t=-2,603 ; p<0,05)$ göre istatistiksel olarak anlamlı farklılıklar gösterdiği belirlenmiştir. Buna göre erkeklerin tutum boyutuna ilişkin algıları istatistiksel olarak anlamlı şekilde kızlara göre daha yüksektir.

Katılımcıların algı alt boyutuna vermiş oldukları puanları çeşitli değişkenlere göre karşılaştıran test sonuçlarına bakıldığında ise, katılımcıların bu boyuta ilişkin puanlarının yaşlarına $(t=-2,105 ; p<0,05)$ ve ikamet edilen yere $(F=3,235 ; p<0,05)$ göre istatistiksel olarak anlamlı farklılıklar gösterdiği belirlenmiştir. Buna göre yaşı 20 ve üzeri olanların ve arkadaşlarıyla veya tek başına evde kalanların algı boyutuna ilişkin algıları istatistiksel olarak anlamlı şekilde daha yüksek bulunmuştur.

Son olarak katılımcıların harcama alt boyutuna vermiş oldukları puanları çeşitli değişkenlere göre karşılaştıran test sonuçlarına bakıldığında, katılımcıların bu boyuta ilişkin puanlarının cinsiyetlerine ( $t=-2,880 ; p<0,05)$, sınıf düzeylerine $(F=3,555 ; p<0,05)$ ve ikamet edilen yere $(F=3,467$; $p<0,05)$ göre istatistiksel olarak anlamlı farklılıklar gösterdiği belirlenmiştir. Buna göre erkeklerin, üçüncü sınıf öğrencilerin ve arkadaşlarıyla veya tek başına evde kalanIarın harcama boyutuna ilişkin algıları istatistiksel olarak anlamlı şekilde daha yüksektir.

\section{Tartışma ve sonuç}

Bireylerin finansal konulardaki bilgi düzeyleri ile beraber finansal tutum ve davranışları finansal okuryazarlık düzeylerini etkilemektedir. Örneğin; bireylerin finansal tutum ve davranışları, geleceğe yönelik harcama, birikim yapma gibi parasal konularda alınacak kararlarını etkilemektedir (15). Finansal okuryazarlık bir kişinin finansal kararlarını doğrudan etkileyebilmesi nedeniyle; bireylerin, paralarını yönetebilmek, aylık bütçe giderlerini belirlemek ve günlük harcamalarını kontrol edebilmek gibi finansal okuryazarlıklarını iyileştirmek için olumlu özellik ve alışkanlıklar geliştirmesi gerekmektedir (16). Ancak bu gibi özellik ve alışkanlıkların bireylere lise veya üniversite çağında kazandırıması bireylerin hayatlarının ileriki dönemlerinde 
Tablo 3. Araştırmaya katılan öğrencilerin çeşitli değişkenlere göre finansal okuryazarlık alt boyutlarına ilişkin puanları

\begin{tabular}{|c|c|c|c|c|c|c|c|c|}
\hline \multirow[t]{2}{*}{ Değişkenler } & \multicolumn{2}{|c|}{ ilgi } & \multicolumn{2}{|c|}{ Tutum } & \multicolumn{2}{|c|}{ AlgI } & \multicolumn{2}{|c|}{ Harcama } \\
\hline & Ort. & S.S. & Ort. & S.S. & Ort. & S.S. & Ort. & S.S. \\
\hline \multicolumn{9}{|l|}{ Yaş (yıl) } \\
\hline $19 \leq$ & 3,15 & 0,72 & 1,97 & 0,69 & 1,95 & 0,80 & 2,65 & 0,62 \\
\hline \multirow[t]{2}{*}{$20 \geq$} & 3,13 & 0,80 & 1,98 & 0,64 & 2,18 & 0,95 & 2,76 & 0,70 \\
\hline & \multicolumn{2}{|c|}{$\begin{array}{l}t=0,256 ; \\
p=0,798\end{array}$} & \multicolumn{2}{|c|}{$\begin{array}{c}t=-0,099 \\
p=0,921\end{array}$} & \multicolumn{2}{|c|}{$\begin{array}{l}t=-2,105 ; \\
p=0,036\end{array}$} & \multicolumn{2}{|c|}{$\begin{array}{l}t=-1,379 \\
p=0,169\end{array}$} \\
\hline \multicolumn{9}{|l|}{ Cinsiyet } \\
\hline KIZ & 3,30 & 0,70 & 1,91 & 0,63 & 2,01 & 0,86 & 2,63 & 0,63 \\
\hline \multirow[t]{2}{*}{ Erkek } & 2,76 & 0,77 & 2,14 & 0,71 & 2,21 & 0,94 & 2,89 & 0,71 \\
\hline & \multicolumn{2}{|c|}{$\begin{array}{l}t=5,666 \\
p=0,000\end{array}$} & \multicolumn{2}{|c|}{$\begin{array}{c}t=-2,603 \\
p=0,010\end{array}$} & \multicolumn{2}{|c|}{$\begin{array}{c}t=-1,714 \\
p=0,088\end{array}$} & \multicolumn{2}{|c|}{$\begin{array}{l}t=-2,880 \\
p=0,004\end{array}$} \\
\hline \multicolumn{9}{|l|}{ Sinif } \\
\hline Birinci Sınif (1) & 3,05 & 0,68 & 1,94 & 0,68 & 1,99 & 0,85 & 2,54 & 0,57 \\
\hline İkinci Sınıf (2) & 3,26 & 0,82 & 2,00 & 0,70 & 2,07 & 0,93 & 2,80 & 0,65 \\
\hline Üçüncü Sınıf (3) & 3,08 & 0,78 & 1,98 & 0,64 & 2,00 & 0,83 & 2,83 & 0,81 \\
\hline \multirow[t]{2}{*}{ Dördüncü Sınıf (4) } & 3,18 & 0,78 & 2,00 & 0,55 & 2,35 & 0,91 & 2,76 & 0,68 \\
\hline & \multicolumn{2}{|c|}{$\begin{array}{l}F=1,482 \\
p=0,220\end{array}$} & \multicolumn{2}{|c|}{$\begin{array}{l}F=0,139 ; \\
p=0,937\end{array}$} & \multicolumn{2}{|c|}{$\begin{array}{l}F=1,579 ; \\
p=0,195\end{array}$} & \multicolumn{2}{|c|}{$\begin{array}{c}F=3,555 ; \\
p=0,015 \\
1-2 ; p=0,026\end{array}$} \\
\hline \multicolumn{9}{|l|}{ İkamet Ettiğiniz Yer } \\
\hline $\begin{array}{l}\text { Aile/Akraba } \\
\text { yanında (1) }\end{array}$ & 2,83 & 0,73 & 1,81 & 0,55 & 1,85 & 0,78 & 2,46 & 0,66 \\
\hline Yurtta (2) & 3,21 & 0,76 & 2,05 & 0,69 & 2,17 & 0,89 & 2,71 & 0,67 \\
\hline $\begin{array}{l}\text { Arkadaşlarımla } \\
\text { birlikte/Tek başına } \\
\text { evde (3) }\end{array}$ & 2,93 & 0,79 & 2,04 & 0,76 & 2,24 & 0,98 & 2,95 & 0,71 \\
\hline \multirow[t]{2}{*}{ Apart/Pansiyon (4) } & 3,29 & 0,70 & 1,85 & 0,55 & 1,85 & 0,79 & 2,65 & 0,59 \\
\hline & \multicolumn{2}{|c|}{$\begin{array}{c}F=4,058 \\
p=0,008 \\
1-4 ; p=0,030\end{array}$} & \multicolumn{2}{|c|}{$\begin{array}{l}F=2,104 \\
p=0,100\end{array}$} & \multicolumn{2}{|c|}{$\begin{array}{c}F=3,235 \\
p=0,023\end{array}$} & \multicolumn{2}{|c|}{$\begin{array}{c}F=3,467 \\
p=0,017 \\
1-3 ; p=0,012\end{array}$} \\
\hline $\begin{array}{l}\text { Ortalama Aylık } \\
\text { Aile Geliri }\end{array}$ & & & & & & & & \\
\hline 1000 TL'den az & 3,22 & 0,83 & 2,02 & 0,76 & 2,32 & 0,97 & 2,69 & 0,68 \\
\hline $1001-1500 \mathrm{TL}$ & 3,22 & 0,75 & 1,92 & 0,64 & 1,99 & 0,77 & 2,67 & 0,61 \\
\hline $1501-2000 \mathrm{TL}$ & 3,01 & 0,70 & 1,96 & 0,61 & 2,06 & 0,92 & 2,76 & 0,57 \\
\hline 2001 TL ve üstü & 3,10 & 0,76 & 2,02 & 0,64 & 1,92 & 0,85 & 2,72 & 0,79 \\
\hline & $\begin{array}{l}F= \\
p=\end{array}$ & $\begin{array}{l}\text {,205; } \\
, 308\end{array}$ & & , & $\begin{array}{l}F=2 \\
p=\end{array}$ & $\begin{array}{l}, 614 ; \\
, 052\end{array}$ & & $\begin{array}{l}239 \\
869\end{array}$ \\
\hline İş Deneyimi & & & & & & & & \\
\hline Var & 2,98 & 0,75 & 1,88 & 0,64 & 2,00 & 0,90 & 2,75 & 0,65 \\
\hline Yok & 3,25 & 0,75 & 2,04 & 0,67 & 2,11 & 0,87 & 2,67 & 0,67 \\
\hline & $\begin{array}{l}t=-2 \\
p=\end{array}$ & , & $\begin{array}{l}t=- \\
p=\end{array}$ & , & $\begin{array}{l}t=- \\
p=\end{array}$ & $\begin{array}{l}001 ; \\
, 318\end{array}$ & & $\begin{array}{l}966 ; \\
335\end{array}$ \\
\hline
\end{tabular}

finansal konularda daha kolay ve bilinçli karar almalarını sağlayacaktır. Bu yüzden üniversite öğrencilerinin finansal okuryazarlığın önemini çok iyi anlamaları ve finansal konularda yeterli eğitimleri almaları gerekmektedir.

Bu çalışmada sağlık yönetimi bölümü öğrencilerinin finansal okuryazarlık düzeylerini belirlemek ve demografik özelliklerin finansal okuryazarlık üzerinde etkili olup olmadığını ortaya koymak amaçlanmıştır. Çalışma sonucunda, öğrencilerin finansal okuryazarlık algılarının boyutlar bazında orta seviyede olduğu belirlenmiştir. Öğrencilerin tutum boyutuna ilişkin algıları ise oldukça düşük düzeyde tespit edilmiştir. Barmaki (2015)'nin üniversite öğrencilerinde yaptığı çalışmasında öğrencilerin finansal okuryazarlık düzeylerinin orta düzeyde olduğu bulunmuştur (13). Çam ve Barut (2015)'un önlisans öğrencilerinde yürüttükleri çalışmalarında ise öğrencilerin finansal okuryazar olmadıkları ve temel finansal kavramlar hakkında çok az bilgiye sahip oldukları belirlenmiştir (17). Bayram (2010)'ın çalışmasında öğrencilerin finansal okuryazarlık düzeyinin oldukça düşük olduğu ve bu durumun farkında olunmadığı sonucuna ulaşılmıştır (18). Çoşkun (2016)'un çalışma sonucunda da öğrencilerin finansal okuryazarlık düzeyinin düşük bir oranda olduğu tespit edilmiştir (19). Temizel ve Bayram (2011)'ın öğrencilerin temel düzeyde finansal okuryazarlık seviyesini belirlenmeye çalıştıkları çalışmalarında ise öğrencilerin finansal durumlarını yönetmede kendilerini olduğundan daha başarılı olarak algıladıkları belirlenmiştir (12). Cameron vd. (2013)'nin Yeni Zelenda, Japonya ve Amerika'daki lise öğrencilerinde finansal okuryazarlık durumunu karşılaştırmak amacıyla yürüttükleri çalışmalarında finansal okuryazarlığın üç ülkede de genel olarak düşük olduğu ve bu durumun Yeni Zelanda'da ve ABD'de Japonya'dan daha kötü olduğunu belirlemişlerdir (20). Moon vd. (2014)'nin Çinli üniversite öğrencileri üzerinde gerçekleştirdikleri çalışmalarında ise öğrencilerin genel finansal okuryazarlık puanlarının Kore ve diğer OECD üye ülkelerinkinden daha düşük olduğu tespit edilmiştir (21).

Araştırma kapsamında yer alan sağlık yönetimi bölümü öğrencilerinin finansal okuryazarlık alt boyutlarından ilgi alt boyutuna vermiş oldukları puanları cinsiyet, ikamet edilen yer ve iş deneyiminin olup olmamasına göre anlamlı bir farklılık gösterdiği tespit edilmiştir. Buna göre kızların, apart/pansiyonda kalanların ve iş deneyimi olmayanların ilgi boyutuna ilişkin algıları istatistiksel olarak anlamlı şekilde daha yüksek bulunmuştur. Bu çalışmaya göre kızların finansal konulara erkeklerden daha ilgili oldukları belirtilebilir. Chen ve Volpe (1998)'ün öğrencilerin finansal okuryazarlık durumlarını inceledikleri çalışmalarında 
öğrencilerin cinsiyetleri ve iş deneyimleri ile finansal okuryazarlık arasında anlamlı farklılık bulunmuş, kadınların ve daha az iş tecrübesi olan öğrencilerin finansal okuryazarlık bilgi düzeylerinin daha düşük olduğu tespit edilmiştir (22). Beal ve Delpachitra (2003)'nın Avustralyalı öğrencilerde yaptıkları çalışmalarında ise erkek öğrencilerde, gelir düzeyi yüksek olanlarda ve daha fazla iş deneyimine sahip olanlarda finansal okuryazarlık puanları daha yüksek bulunmuştur (23). Biç̧er ve Altan (2016)'nın üniversite öğrencileri üzerinde gerçekleştirmiş olduğu çalışmalarında ise öğrencilerin sınıf düzeylerine göre anlamlı farklılık tespit edilmiş ve birinci sınıfların ilgi puanları diğer sınıf düzeylerine göre daha düşük bulunmuştur (24). Bu çalışmada da anlamlı fark bulunmasa da birinci sınıfların ilgi puanları daha düşük bulunmuştur. Bu durumun öğrencilerin finans, muhasebe gibi dersleri daha yeni görmeye başladığından ve bu konular hakkında farkındalıklarının daha az olmasından kaynaklandığı düşünülmektedir.

Çalışmada, öğrencilerin tutum alt boyutuna vermiş oldukları puanların cinsiyetlerine göre istatistiksel olarak anlamI farklılıklar gösterdiği belirlenmiştir. Buna göre erkeklerin tutum boyutuna ilişkin algıları istatistiksel olarak anlamlı şekilde daha yüksek tespit edilmiştir. Biçer ve Altan (2016)'nın çalışmasında ise tutum boyutunda cinsiyete göre anlamlı farklılık bulunmamakla birlikle kadınların puanlarının erkeklerden daha yüksek olduğu bulunmuştur (24). Ancak çalışmada genel olarak bir değerlendirme yapıldığında öğrencilerin tutum puanlarının düşük olduğu görülmektedir. Bu durum öğrencilerin haftalık ve aylık harcama planlarına daha az dikkat ettiğini, alışveriş yaparken fiyat kıyaslamalarına çok fazla önem vermedikleri gibi sonuçları ortaya çıkarmaktadır.

Çalışmada öğrencilerin algı alt boyutuna vermiş oldukları puanları yaşlarına ve ikamet edilen yere göre istatistiksel olarak anlamlı farklılıklar gösterdiği belirlenmiştir. Buna göre yaşı 20 ve üzeri olanların ve arkadaşlarıyla veya tek başına evde kalanların algı boyutuna ilişkin değerlendirmeleri istatistiksel olarak anlamlı şekilde daha yüksek bulunmuştur. Biçer ve Altan (2016)'ın çalışmalarında ise algı boyutunda öğrencilerin sınıf düzeylerine göre anlamlı farklılık tespit edilmiş ve dördüncü sınıfların algı puanları diğer sınıf düzeylerine göre daha düşük bulunmuştur (24). Bu çalışmada da anlamlı fark bulunmasa da birinci sınıfların algı puanları daha düşük bulunmuştur. Adeleke (2013)'nin üniversite öğrencileri üzerinde gerçekleştirdiği çalışmasında öğrencilerin cinsiyetleri ile finansal okuryazarlık düzeyleri arasında anlamlı bir ilişki bulunamamış ancak öğrencinin yaşı ile finansal okuryazarlık düzeyleri arasında anlamlı bir ilişki bulunmuştur (25). Ansong ve
Gyensare (2012)'nin Gana'da yaptıkları çalışmalarında ise yaş ve iş deneyimi ile finansal okuryazarlık düzeyi arasında anlamlı pozitif ilişsiler bulunmuştur (26).

Son olarak katılımcıların harcama alt boyutuna vermiş oldukları puanları cinsiyetlerine, sınıf düzeylerine ve ikamet edilen yere göre istatistiksel olarak anlamlı farklılıklar gösterdiği belirlenmiştir. Buna göre erkeklerin, üçüncü sınıf öğrencilerin ve arkadaşlarıyla veya tek başına evde kalanların harcama boyutuna ilişkin algıları istatistiksel olarak anlamlı şekilde daha yüksektir. Biçer ve Altan (2016)'nın çalışmalarında ise harcama boyutunda öğrencilerin cinsiyetlerine ve sınıf düzeylerine göre istatistiksel olarak anlamlı bir fark bulunmasa da kızların ve ikinci sınıfların ortalamaları daha yüksek bulunmuştur (24). Moon vd. (2014)'nin çalışmalarında ise harcama boyutunda cinsiyete göre anlamlı bir fark bulunmuş ve erkek öğrencilerin harcamaya yönelik algıları kadın öğrencilerden daha yüksek olarak belirlenmiştir (21). Hwa vd. (2013)'nin çalışmasında ise cinsiyet ile finansal okuryazarlık ve aylık harcamalar arasında anlamlı bir farklılık bulunamamıştır (16). Şamiloğlu vd. (2016)'nin üniversite öğrencileri üzerinde yaptıkları çalışmalarında erkek öğrencilerin kız öğrencilerden daha iyi finansal okuryazarlık seviyesine sahip olduğu bulunmuştur (10). Tüfekçi vd. (2017)'nin işletme bölümü öğrencileri üzerinde gerçekleştirdikleri çalışmalarında ise finansal bilgi düzeyinin kız öğrencilerde erkek öğrencilere göre daha yüksek olduğu belirlenmiştir. Ayrıca dördüncü sınıf öğrencileriyle birinci ve ikinci sınıf öğrencileri arasında finansal bilgi düzeyi açısından istatistiki olarak anlamlı bir fark çıkmıştır (27).

Geleceğin sağlıkyöneticisi adayı olan sağlıkyönetimi öğrencilerinin finansal konulara yönelik tutum ve davranışlarının belirlenmesinin önemli olduğu düşünülmektedir. Özellikle bu öğrencilerin kaynakları nasıl yönetecekleri, finansal kararları nasıl alacakları, hangi finansal araçları kullanmaları gerektiği gibi pek çok konuda bilgi sahibi olmaları gerekmektedir. Bu yüzden de birçok sağlık yönetimi bölümlerinin ders müfredatında finansal yönetim, muhasebe, ekonomi gibi dersler bulunmaktadır. Ancak bu bilgilerin daha fazla işlerlik kazanabilmesi ve bu konulardaki farkındalıkların artırılabilmesi için finansal okuryazarlık gibi spesifik eğitimlerin de öğrencilere kazandırıması faydalı olacaktır.

Bu çalışmanın sonuçlarının tüm sağlık yönetimi bölümü öğrencilerine genellenmesi konusunda sınırlılıkları bulunmaktadır. Araştırmanın örneklemi Türkiye'nin bir ilinde ve bir devlet üniversitesinde okuyan öğrenciler oluşmaktadır. Gelecekte daha genişörneklemlerle yapılacak çalışmaların daha etkili sonuçlar ortaya koyabileceği düşünülmektedir. 


\section{Kaynaklar}

1. Kılıç Y, Ata HA, Seyrek IH. Finansal okuryazarlık: üniversite öğrencilerine yönelik bir araştırma. Muhasebe ve Finansman Dergisi 2015; 129-50.

2. Al-Tamimi $\mathrm{HAH}$, Bin Kalli AA. Financial literacy and investment decisions of UAE investors. The Journal of Risk Finance 2009;10:50016. [CrossRef]

3. Clark GL. Financial literacy in context 2013. Erişim Adresi: http://www. geog.ox.ac.uk/events/120927/glclark.pdf (Erişim tarihi:16.04.2019)

4. Remund DL. Financial literacy explicated: the case for a clearer definition in an increasingly complex economy. The Journal of Consumer Affairs 2010; 44:276-95. [CrossRef]

5. OECD. Financial literacy and inclusion: results of OECD/INFE survey across countries and by gender. OECD Centre, Paris, France, 2013.

6. Huston SJ. Measuring financial literacy. The Journal of Consumer Affairs 2010; 44:296-316. [CrossRef]

7. Wachira MI, Kihiu EN. Impact of financial literacy on access to financial services in Kenya. International Journal of Business and Social Science 2012; 3:42-50.

8. Karataş Ç. Finansal okuryazarlığın geliştirilmesinde merkez bankalarının rolü ve Türkiye Cumhuriyet Merkez Bankası için bir değerlendirme. Türkiye Cumhuriyet Merkez Bankası Uzmanlık Yeterlik Tezi, Ankara, 2017.

9. Er F, Temizel F, Özdemir A, Sönmez H. Lisans eğitim programlarının finansal okuryazarlık düzeyine etkisinin araştırılması: Türkiye örneği. Anadolu Üniversitesi Sosyal Bilimler Dergisi 2014; 14:113-26.

10. Şamiloğlu F, Kahraman YE, Bağcı H. Finansal okuryazarlık araştırması: Erciyes Üniversitesi öğrencileri üzerinde bir uygulama. Uluslararası Yönetim İktisat ve İşletme Dergisi 2016; ICAFR 16 Özel Sayısı, 308-18. [CrossRef]

11. Gökmen H. Finansal okuryazarlık. İstanbul: Hiperlink Yayınları; 2012. p.24.

12. Temizel F, Bayram F. Finansal okuryazarlık: Anadolu Üniversitesi İktisadi İdari Bilimler Fakültesi (iiBF) öğrencilerine yönelik bir araştırma. Ç.Ü. İktisadi ve İdari Bilimler Dergisi 2011; 12:73-86.

13. Barmaki N. Üniversite öğrencilerinin finansal okuryazarlık düzeylerini belirlemeye yönelik bir araştırma: Hacettepe Üniversitesi örneği. Hacettepe Üniversitesi Sosyal Bilimler Enstitüsü. Yayınlanmamış Yüksek Lisans Tezi, Ankara, 2015.

14. Sarıgül H. Finansal okuryazarlık tutum ve davranış ölçeği geliştirme, geçerlik ve güvenirlik. Yönetim ve Ekonomi Araştırmaları Dergisi 2015;13:200-18. [CrossRef]
15. Alkaya A, Yağlı İ. Finansal okuryazarlık, finansal bilgi, davranış ve tutum: Nevşehir Hacı Bektaş Veli Üniversitesi iïBF öğrencileri üzerine bir uygulama. Uluslararası Sosyal Araştırmalar Dergisi 2015;8:585-99.

16. Hwa NC, Bei TS, Ying VKW, Cheng YY. Personal financial literacy among tertiary level students. Faculty of Business and Finance Department of Finance, Universiti Tunku Abdul Rahman; 2013.

17. Çam AV, Barut A. Finansal okuryazarlık düzeyi ve davranışları: Gümüşhane Üniversitesi önlisans öğrencileri üzerine bir araştırma. Küresel İktisat ve İşletme Çalışmaları Dergisi 2015;4:63-72.

18. Bayram SS. Finansal okuryazarlık ve para yönetimi davranışları: Anadolu Üniversitesi öğrencileri üzerine uygulama. Anadolu Üniversitesi Sosyal Bilimler Enstitüsü Yayınlanmamış Yüksek Lisans Tezi, Eskişehir, 2010.

19. Coşkun S. Üniversite öğrencilerinin finansal davranış ve tutumlarının belirlenmesi: finansal okuryazarlık algıları üzerine bir araştırma. İnsan ve Toplum Bilimleri Araştırmaları Dergisi 2016; 5:2247-58.

20. Cameron MP, Calderwood R, Cox A, Lim S, Yamaoka M. Personal financial literacy among high school students in New Zealand, Japan and the USA. Citizenship, Social and Economics Education 2013; 12:200-15. [CrossRef]

21. Moon CS, Ohk K, Choi C. Gender differences in financial literacy among Chinese University students and the influential factors. Asian Women 2014; 30:3-25.

22. Chen $\mathrm{H}$, Volpe RP. An analysis of personal finance literacy among college students. Financial Services Review 1998;7:107-28.

23. Beal DJ, Delpachitra SB. Financial liteyacy among Australian University students. Economic Papers 2003; 22:65-78. [CrossRef]

24. Biçer EB, Altan F. Üniversite öğrencilerinin finansal okuryazarlık ile ilgili tutum ve davranışlarının değerlendirilmesi. Atatürk Üniversitesi Sosyal Bilimler Enstitüsü Dergisi 2016; 20:1501-17.

25. Adeleke T. The effects of gender and gender role on the financial literacy of college students [Master Thesis]. University of North Carolina Wilmington, North Carolina, 2013.

26. Ansong A, Gyensare MA. Determinants of university workingstudents' financial literacy at the University of Cape Coast. Ghana, International Journal of Business and Management 2012;7:126-33. doi:10.5539/ijbm.v7n9p126

27. Tüfekçi B, Erdoğan S, Karaca SS, Seçgin N. Finansal okuryazarlık bilgi düzeylerinin ölçülmesi: İşletme Bölümü öğrencileri üzerine bir uygulama. 2. Lisansüstü İşletme Öğrencileri Sempozyumu, 20-22 Nisan, Bursa, 2017. 